\title{
Kinanthropometry in Brazilian Physical Education (1970s): a new knowledge perspective for this field
}

\section{A Cineantropometria na Educação Física brasileira (década de 1970): uma nova perspectiva de conhecimento para o campo}

Carolina Fernandes da Silva ${ }^{1}$

(D) https://orcid.org/0000-0003-0026-1318

Luiz Felipe Guarise Katcipis ${ }^{1}$

(D) https://orcid.org/0000-0002-1696-5718

Bruna Letícia de Borba ${ }^{\top}$

(D) https://orcid.org/0000-0001-6679-1974

Alice Francisco Freitas ${ }^{1}$

(D) https://orcid.org/0000-0001-9851-5376

Abstract - The aim of the present study is to understand the constitution of kinanthropometry as scientific disciplinary field in the 1970s in Brazil. Therefore, a bibliographic review was carried out in nine databases and in a specific journal focused on publications from the Kinanthopometry perspective, since this is an element to legitimize a scientific discipline. Only two studies dealing with this topic were selected. Given such a gap in the literature, three interviews with professors who organized the Physical Education (PE) course laboratories, as well as a newspaper report from the period, were used in the study. Different names have been associated with the scientific field of human composition assessment throughout history, as well as formulating different body perceptions, such as Biometrics, Anthropometry and kinanthropometry. Each of these factors determine relationships with the involved socio-cultural context. Such a complexity to understand a conjecture within a historical time expands the space available for analyses. In the 1960s, the term kinanthropometry emerged in foreign countries as a new way of interpreting human body composition assessments linked to knowledge in the PE field based on movement and anatomy. This term was imported by Brazilian researchers after their contact with scientists in USA and Canada, since it offered the possibility of acquiring new representations for research in the PE field back in the 1970s.

Key words: History; Kinanthropometry; Knowledge; Natural science disciplines.

Resumo - O presente estudo visa compreender a constituição da Cineantropometria como campo disciplinar cientifico na década de 1970 no Brasil. Para tanto, foi realizada uma revisão bibliográfica em nove bases de dados e no exclusivo periódico com foco específico em publicaçôes na perspectiva da Cineantropometria, por este ser um elemento para a legitimaçẫo de uma disciplina cientifica. Foram identificados apenas dois estudos que tratam sobre a história da Cineantropometria como campo disciplinar. Diante desta lacuna, foram utilizadas três entrevistas com professores que organizaram os laboratórios dos cursos de Educação Física (EF), bem como uma reportagem de jornal do período. Diferentes denominaçôes estiveram ligadas ao longo da história do campo cientifico da avaliação da composição corporal humana, formulando distintas percepções de corpo, como a Biometria, a Antropometria e a Cineantropometria, cada qual estabelecendo relaçóes com o contexto sociocultural que as envolvia. Nessa complexidade para compreender uma conjectura dentro de um tempo histórico, amplia- se espaço e tempo de análise. Em países do exterior, na década de 1960, o termo Cineantropometria surge como nova forma de interpretação da avaliação da composição corporal humana, vinculado aos conhecimentos do campo da EF, pautada em movimento e anatomia. Com o contato dos pesquisadores brasileiros com cientistas dos Estados Unidos e do Canadá, este termo é importado e oferece uma possibilidade de aquisição de novas representaçôes para a pesquisa em EF na década de 1970.

Palavras-chave: Cineantropometria; Conhecimento; Disciplinas das ciências naturais; História.
1 Federal University of Santa Catarina. Florianópolis, SC. Brazil.

Received: May 03, 2020 Accepted: September 29, 2020

How to cite this article Silva CF, Katcipis LFG, Borba BL, Freitas AF. Kinanthropometry in Brazilian Physical Education (1970s): a new knowledge perspective for this field. Rev Bras Cineantropom Desempenho Hum 2020, 22:e75281. D0l: http://dx.doi. org/10.1590/1980-0037.2020v22e75281

Copyright: This work is licensed under a Creative Commons Attribution 4.0 International License. 


\section{INTRODUCTION}

The evaluation of human body composition is historically observed in several research fields, such as Kinanthropometry, which is a sub-discipline in the scientific field of Physical Education ${ }^{1}$; this procedure was introduced in Brazil in the 1970s. According to Fourez ${ }^{2}$, associations established between scientific discipline and socio-cultural context are based on a mental organization he called paradigm, which aims at better understanding the world by creating ways of approaching and classifying it. Thus, every paradigm tries to create a domain over a given phenomenon by assigning concepts resulting from possible ways of interpreting reality. According to Beunen and Borms ${ }^{3}$, Kinanthropometry is a scientific disciplinary field focused on investigating the association between structure and human movement; its multidisciplinary nature is its greatest asset ${ }^{4}$.

Different names have been attributed to the scientific field of human body composition assessment and formulated different perceptions about human body. Among them, one finds Biometrics, Anthropometry and Kinanthropometry; each one of them establishes different associations with the sociocultural context involving them ${ }^{5}$. According to Fourez ${ }^{2}$, reality is understood through structured forms of analysis based on valuing differences. Therefore, it is necessary observing the cultural conditions of a given period in order to understand changes taking place in a given scientific context, since each discipline proposes a new approach to the world, in association with the culture of its time ${ }^{2}$.

Knowledge has a perspective bias, i.e., no attempt to know reality [...] can escape its own circumstances or existence conditions, mainly the social ones $^{6}$. Thus, assumingly, based on the historical-social context analysis, it is possible finding evidence of elements capable of showing how a given multidisciplinary scientific perspective emerged at a given time in Brazilian Physical Education (PE).

During its historical training process, Physical Education (PE) aimed at investigating body composition in Brazil until the 1970s, and mainly established dialogues with research theories about human body in disciplines such as Biometrics and Anthropometry ${ }^{5,7}$. At that time, these theories had already been established in the undergraduate discipline matrix of Brazilian universities; their logic was focused on standardizing human body measurement techniques to enable better control over the research method adopted to investigate the object of study based on scientific-universality parameters ${ }^{2}$. Subsequently, the term Kinanthropometry has emerged as new research concept in the PE field. Kinanthropometry did not replace Anthropometry, but it used anthropometric techniques to help broadening the understanding about variables associated with growth, physical activity and nutritional state ${ }^{7}$.

In light of the foregoing, the aim of the current study was to investigate the consolidation of Kinanthropometry as scientific disciplinary field in the 1970s, in Brazil. 


\section{DEVELOPMENT}

The current study relied on theoretical and methodological assumptions of History and on philosophical concepts of science in order to analyze the time in the past when Kinanthropometry was introduced in the Brazilian scientific reality. In order to do so, the research focused on the assumption that history enables human construction, the narrative of the past, which is involved and defined by experiences lived by individuals within a particular time; these experiences enable making adjustments to reality in order to better understand the world ${ }^{8}$.

A bibliographic review was carried out in the following databases: Taylor \& Francis, Web of Science, LILACS, PubMed, Dialnet, SciELO, Latindex; CAPES Journal Portal, as well as at the webpage of the Brazilian Journal of Kinanthropometry \& Human Performance (RBCDH - Revista Brasileira de Cineantropometria \&Desempenho Humano). This Brazilian journal was included in the search because it is the only journal focused on publications specifically based on the Kinanthropometry perspective since 1999, because it is an element capable of legitimizing a scientific discipline. The following terms were used in the search: kinanthropometry AND history; kinanthropometry AND science; kinanthropometry AND philosophy; and kinanthropometry AND discipline. It is noteworthy that these terms were used in English on the first eight platforms, and in Portuguese, on CAPES Journal Portal. The search conducted at RBCDH was based on terms such as history, science, discipline and philosophy; it resulted in two articles about the history of Kinanthropometry, one international article written in English ${ }^{1}$, and another one, in Portuguese 9 . The Article written in Portuguese was a literature review of international scope and it did not address the trajectory of Kinanthropometry in Brazil based on the theoretical-methodological framework of History.

Given this gap, the current study has sought information in documentary sources. Three interviews conducted with teachers who organized the $\mathrm{PE}$ course laboratories were used to compose the documentary corpus in the current research; this corpus was organized to present a sequence of narratives capable of producing meaning ${ }^{8}$ - the aforementioned interviews are available at the website of the journal called Movimento ${ }^{10}$. A search for socio-cultural representations of Kinanthropometry was also carried out in Brazilian newspapers from the 1970s, in the Digital Newspaper Library of the National Library of Brazil, where only the term 'Biometrics' was found - likely because the insertion process of this disciplinary field in $\mathrm{PE}$ is still in course.

These documents were featured throughout the discussion, since the treatment applied to historical sources was based on the indiciary paradigm perspective, which enables the intensive analysis of sources and incorporates them to the narrative. The indiciary knowledge body is a complex concept that overall refers to the ability to recover a complex non-experimentable reality, based on apparently negligible data. ${ }^{11}$ The indiciary paradigm ${ }^{11}$ deals 
with the likelihood of elucidating a given problem and requires researchers to be attentive to signs and clues left by their object, through the intensive analysis of sources.

The narrative of the current article was structured into two topics. The first topic presents the organization of Kinanthropometry paradigms used to establish it as disciplinary field. The second topic, which starts from contextual aspects raised in the first topic, has its narrative focused on the social scenario developed around the assessment of human body composition as a Kinanthropometry knowledge field linked to PE in the 1970s, in Brazil.

\section{Paradigm formation: Physical Education and Kinanthropometry}

Throughout the 19 th century, science was consolidated as one of the main epistemological currents worldwide, since it was capable of influencing several knowledge fields through its method used to analyze phenomena taking place within reality. This movement gave rise to scientific studies about humans, such as Anthropology ${ }^{12}$.

According to Williams ${ }^{12}$, studies about Anthropology conducted in the $19^{\text {th }}$ century based their considerations about humans on the psychological and physical perspectives in order to better understand how the association of the two perspectives resulted in laws expressed in sensations and movements. However, according to the aforementioned author ${ }^{12}$, there was prevalence of studies based on the physical perspective, be them associated with human senses or with the physical diversity linked to the idea of human evolution. These studies gave rise to what is nowadays called Physical Anthropology, as seen in medical studies conducted in the late $18^{\text {th }}$ and early $19^{\text {th }}$ centuries in Europe - mainly in France and England - which highlighted a movement focused on establishing nation-states ${ }^{13}$. Different devices were developed and used during this period in order to investigate body mass oscillations and to compare them to the health status of individuals' bodies ${ }^{13}$.

Thus, the development of new measurement techniques based on other aspects, such as height and circumferences, allowed expanding the use of numbers and measures in the human body scheme and enabled classifying the physical profile of different populations ${ }^{12}$. These concepts have changed as the understanding about Science has also changed.

According to Petroski ${ }^{14}$, the term Anthropometry has Greek origin and refers to the science that holds fundamental merit in studies about Man. Nowadays, it is possible understanding this concept as the study of human body's proportions and measures, as well as the existing association between physical aspect and performance ${ }^{7}$. According to Martins and Waltortt ${ }^{7}$, studies about body composition [...] are feasible due to measurement techniques deriving from Anthropometry.

The human way of thinking is structured through elements associated with the reality of a given historical context, which can be understood 
through the meanings attributed to $\mathrm{it}^{15}$. This association of factors are continuously changed through cultural formation process, which encompasses the epistemological field composed of different knowledge organization forms. Among them, one finds science, which is one of the most legitimate forms, nowadays. According to Fourez ${ }^{2}$, science could be determined as a restricted language code that leads to a movement focused on answering how different life-associated phenomena take place.

When one talks about science, it is often associated with rationalism, since their discourses are in line with some shared ideas, although they are two different perspectives. Reason would be the central point of the epistemological current of rationalism, according to which, for some knowledge to become valid, it must present a logical feature of universal applicability ${ }^{16}$. Under these circumstances, much of the knowledge in the scientific field is organized through the validation received within a social structure that sees a practical and standardized code capable of explaining reality in it. This code enables building the basic rules for each discipline, as well as differentiating and classifying different objects of study.

According to Fourez ${ }^{2}$, the objects of study of each discipline did not exist before them since they are formed and shaped by these disciplines. Therefore, the idea of assessing human body composition is an object of study that was modeled and that acquired new perspectives in different disciplinary fields, such as PE. In the mid-twentieth century, when the scientific field of PE was severely criticized in the United States due to its lack of scientificity, it adopted a new name - Kinesiology - in order to mark a rupture ${ }^{17,18}$. Consequently, new disciplinary perspectives were also incorporated to it.

According to Beunen and Borns ${ }^{3}$, the term Kinanthropometry was first introduced in the scientific field in 1966, at the University of Laval, Quebec, Canada, in order to name a specific discipline used in the university's PE institutes. This term has transformed the way of using and interpreting quantitative measurements and of assessing different aspects of humans in motion. In addition, according to Vangrunderbeek et al. ${ }^{1}$, large-scale kinanthropometric studies and the instruction of new kinanthropometrists would become the main kinanthropometry activities aimed at establishing and legitimizing it as scientific discipline.

When scientific research began to be developed in PE laboratories in Brazil, in the early 1970s, Biometrics and Anthropometry were still used as epistemological basis to assess human body composition. It was just at the end of that decade that Kinanthropometry emerged as a new form of knowledge about human body, whereas Biometrics and Anthropometry started being slowly separated from each other ${ }^{3}$.

\section{Kinanthropometry in Brazilian Physical Education}

According to Quelhas and Nozaki ${ }^{19}$, PE sportsmanship, which started in the 1950s and 1960s, was deepened in the 1970s and 1980s, a fact that transformed sports into a determining element in this field. During this 
period, PE was designed according to State's interests, which were then under the auspices of the Military Dictatorship (1964-1985) that ruled the country after the military coup in 1964 . Based on this perspective, resources were invested in laboratories specialized in training sports in universities.

Based on a PE scientification perspective, the first PE research laboratories were implemented in the 1970s, at the following universities: Federal University of Rio de Janeiro (UFRJ) in $1970^{20}$, Federal University of Rio Grande do Sul (UFRGS) in $1972^{10}$, and Municipal University of São Caetano do Sul - (USCS) in 197421. Such investments were disclosed by a sports-specialized newspaper widely disseminated in Brazil, called "Jornal dos Sports". One of its publications, in 1977, enabled seeing that the term Biometrics was still used by the press, likely because it was the term best known by newspaper's readers. This publication established associations among science, sports practice and performance, based on biomedical perspectives:

Based on instructions provided by Minister Ney Braga, the Department of Education and Sports of the Ministry of Education and Culture has been investing resources (it had invested 20 million cruzeiros until 1979) in Universities in order to encourage and develop specialized laboratories to support sports training. [...] According to the plan, fields such as effort physiology, biometrics, biomechanics and physical pedagogy are getting support in the main sports centers in the country, which will certainly enable our athletes to show the best physical performance, based on modern medical criteria ${ }^{22}$.

The first stricto sensu postgraduate course in $\mathrm{PE}$ was launched during this period, due to the implementation of the Master's degree course in PE at University of São Paulo (USP) and, subsequently, to the implementation of the Master's degree course in Motion Science at Federal University of Santa Maria (UFSM), in $1979^{23}$.

Such spaces were created to improve the training of athletes, because the federal government had started investing in sports during this period in order to improve performance indices at the Olympic Games ${ }^{24-26}$. According to $\mathrm{Mazo}^{26}$, it aimed at finding sports talents, studies focused on assessing the physical fitness of the Brazilian population were one of the solutions presented to help improving the level of participation of Brazilian athletes in international competitions.

Exercise physiology and physical assessment were the main scientific perspectives adopted in these laboratories. The Exercise Research Laboratory (LAPEX - Laboratório de Pesquisa do Exercício) of the Physical Education School (ESEF - Escola de Educação Física) at UFRGS carried out physical evaluation and athletic performance tests in high-performance sports athletes of that period, such as soccer player Edson Arantes do Nascimento (Pelé) and middle-distance runner Joaquim Cruz ${ }^{24}$. Yet, based on the perspective of developing a technical body, individuals' bodies were measured to check their effectiveness and to calculate their potential ${ }^{13}$ for high-performance sports. According to Daólio ${ }^{27}$, in the period before 
the end of the 1970s, "there was certain acceptance that PE was a school practice focused on developing students' physical fitness and on getting them into sports".

However, there is evidence that researchers acted beyond the performance perspective in high-performance sports ${ }^{27}$. Matsudo ${ }^{21}$, who was in charge of LAFISC - later called Center for Studies of São Caetano do Sul Physical Fitness Laboratory (CELAFISC - Centro de Estudos do Laboratório de Aptidão Física de São Caetano do Sul), has stated that this laboratory aimed at evaluating results of sports practices in São Caetano do Sul and at establishing Brazilian fitness and physical activity standards, since all parameters were North American, until then ${ }^{21}$.

Kinanthropometry has emerged in this scenario as one of the most difficult epistemological matrices, as stated by one of the first professors who worked at LAPEX, Eduardo De Rose, in an interview conducted by $\mathrm{Mazo}^{10}$. This researcher has stated that he attributed to the student who had the best mathematical knowledge the task of deepening his knowledge in Kinanthropometry: "He had studied Architecture before he studied Physical Education; [...] he was the only of my students who knew how to do it, because he had studied Calculus I and II. I used to give him the most difficult thing, which was Kinanthropometry, because it required a lot of calculations $" 10$.

This epistemological matrix, among others, was new in Brazil; therefore, it presented limitations to researchers, as stated by another character in the scientific field of $\mathrm{PE}$ in that period, Jorge Pinto Ribeiro ${ }^{10}$, "[...] at that time, we used the technology from the most advanced places in a field that was very new to our environment [...] ergonometry, ergospirometry, muscle biopsy, kinanthropometry: they were all brought to our field." Based on this statement, research conducted in laboratories was still embryonic, new scientific technologies were in the process of being appropriated from other cultures, which were brought to Brazil and translated for country's apprentices. According to Calciolari ${ }^{28}$, after the Sectorial PE-Postgraduate Policy was approved in 1979, the Federal Government's Secretariat for Physical Education and Sports (SEED) has sponsored professors to go to $\mathrm{PE}$ postgraduate courses, mainly in the United States ${ }^{29}$.

After the offer of postgraduate courses in the PE field and the return of professors from abroad with master's and doctoral degree, the principle of the process to build a specific knowledge field for PE became evident. The referent scientific production of that period was, according to Hunger et al..$^{25}$, mainly of biological nature, the academic knowledge about exercise physiology, development, learning and motor control was prioritized, based on the assumption that it would establish the "scientific status of PE"25.

Thus, according to governmental plans, knowledge production was strongly affected by the emergence of laboratories, where studies were conducted to be published in Sports Medicine journals. Studies performed at that time in Brazil, were mainly published in two journals, namely: Revista de Medicina do Esporte, and Revista Brasileira de Ciências do Esporte, 
which started being published in $1978^{10}$. According to Mazo ${ }^{25}$, LAPEX studies conducted from 1973 to 1977 were mainly published in Revista de Medicina do Esporte. The second study produced by this laboratory was entitled "Body composition assessment techniques" ${ }^{30}$.

The establishment of the International Work Group of Kinanthropometry (IWGK) at the annual meeting of the International Council of Sport and Physical Education (ICSPE) held in Brazil in $1978^{1}$ was another important event. In that very same year, researchers started speculating about establishing a "multifunctional scientific society" ${ }^{31}$ in Brazil, where $\mathrm{PE}$ graduates could be accepted as associates; however, their candidacy for the presidency of this institution was forbidden, since it was restricted to doctors. Thus, the Brazilian School of Sports Sciences (CBCE - Colégio Brasileiro de Ciências do Esporte) has emerged and, later, the Brazilian Journal of Sports Sciences (RBCE - Revista Brasileira de Ciências do Esporte) emerged as well, at the late $1970 \mathrm{~s}^{31}$, with representation of Biological Sciences, since this prevalence in Brazilian PE remained until the $1980 \mathrm{~s}^{29}$.

Brazilian PE has imported Kinanthropometry when it was still undergoing legitimation process. It was used to define a disciplinary matrix specific to the PE field, although it was identified as belonging to Sports Medicine. During this period, Kinanthropometry was conceptualized as a scientific discipline for the study of size, shape, proportion and human motor functions in the scientific field of PE. However, according to Vangrunderbeek et $\mathrm{al}^{1}$ (2013), Kinanthropometry was not yet considered a scientific discipline, but a professional training and research technology field, since despite the launching of an association - The International Society for the Advancement of Kinanthropometry (ISAK) -, this scientific field still lacked a peer-reviewed professional journal, which is a fundamental feature of self-referential communication and disciplinary training ${ }^{1}$. The aforementioned authors ${ }^{1}$ also claimed that this issue was never resolved. However, Brazil has the RBCDH, which was established in 1999. This statement evidences the lack of knowledge about scientific improvement actions taken in Brazil.

Therefore, although ISAK $^{33}$ has described Kinanthropometry as the science field associated with human body composition measurement, although it is part of the international scientific reality since the 1960s and, since the 1970s in Brazil, and although it has a specific scientific journal, there are still gaps to be filled. Kinanthropometry must remediate the lack of published books and handbooks titled with this term, as well as the lack of institutes and university courses focused on the theoretical and methodological development in research in this field ${ }^{1}$, in order to make it a scientific discipline.

\section{CONCLUSION}

Based on the compilation of information from different sources - literature, interviews and newspapers - analyzed and interpreted through the lens 
of theoretical-methodological assumptions of History and philosophical concepts of science, it was possible generating the following inferences for the current research.

The term Kinanthropometry has emerged in foreign countries, in the 1960s, as a new way of interpreting human body composition assessment; it was associated with knowledge in the PE field, based on movement and anatomy. The international demand, driven by the Olympic Games, to improve the knowledge about athletes' bodies and performance has led the Brazilian federal government to invest in PE courses to find sports talents, as well as in laboratories in order to develop studies, which were mainly focused on assessing human body composition through anthropometric techniques based on the Sports Medicine perspective, in the early 1970s. These events were reported by newspapers and substantiated the discourse on the need to understand standardizing biological phenomena involved in, and focused on, high-performance sports. The contact between Brazilian researchers and scientists from the United States and Canada allowed importing Kinanthropometry and opened room for the acquisition of new representations for research in $\mathrm{PE}$, as well as for the internationalization of scientific knowledge produced in laboratories, which attributed scientism to the field.

Although Kinanthropometry is part of the reality of the international scientific field of $\mathrm{PE}$ since the mid-20 $0^{\text {th }}$ century and, although Brazil has a specific journal for these studies and research laboratories, it is necessary developing actions to enable consolidating it as scientific discipline. Therefore, Kinanthropometry is perceived as a knowledge production field that uses anthropometric data to be interpreted by theories that associate human body composition measurements with functions attributed to them in the biological perspective; it is interconnected to the sports, school and health fields, in a contextual way, and it is also susceptible to sociocultural changes in space and time.

\section{COMPLIANCE WITH ETHICAL STANDARDS}

\section{Funding}

The current research did not receive any specific grant from funding agencies in the public, commercial, or not-for-profit sectors. This study was funded by the authors themselves.

\section{Ethical approval}

The current research is in compliance with standards set by the Declaration of Helsinki.

\section{Conflict of interest}

The authors declare no conflict of interests.

\section{Author Contributions}

CFS: Elaborated and designed the experiments. CFS, LFGK, BLB and 
AFF: Performed the experiments. CFS, LFGK, BLB and AFF: Analyzed collected data. CFS, LFGK, BLB and AFF: Contributed with reagents/materials/analysis tools. CFS, LFGK, BLB and AFF: Wrote the manuscript.

\section{REFERENCES}

1. Vangrunderbeek H, Claessens AC, Delheye P. Internal social processes of discipline formation: The case of kinanthropometry. Eur J Sport Sci 2013; 13(3): 312-320.

2. Fourez G. A Construção das Ciências: introdução à filosofia e à ética das ciências. Rouanet LP, tradutor. 1. Ed. São Paulo: Ed. da UNESP; 1995. p. 319.

3. Beunen G, Borms J. Cineantropometria: raízes, desenvolvimento e futuro. Rev Bras Cienc Mov 1990; 4(3):1-15.

4. Stewart A. Kinanthropometry - the interdisciplinary discipline. J Sport Science 2007;25(4): 373-373.

5. Fantin SR, Borba BL, Katsipis LF, Freitas AF, Silva CF. A avaliação da composição corporal humana na Educação Física: década de 1970. Silva DAS (org.). Composição corporal humana na Educação Física. 1. Ed. Curitiba: CRV; 2020. p. 11-32.

6. Cupani A. Sobre a ciência: estudos de filosofia da ciência. 1. Ed. Florianópolis: Editora da UFSC; 2018.

7. Martins M, Waltortt L. Antropometria: uma revisão histórica. Petroski E (org.). Antropometria: técnicas e padronizações. 3. Ed. Várzea Paulista, SP: Fontoura; 2011: 9-30.

8. Pesavento SJ. História \& História Cultural. 2. ed. Belo Horizonte: Autêntica; 2008.

9. Michels G. Aspectos históricos da cineantropometria do mundo antigo ao renascimento. Rev Bras Cineantropom Desempenho Hum 2000;2(1): 106-110.

10. Mazo J. Depoimentos dos coordenadores e diretores do LAPEX. Mov 2000;(VI): 23-67.

11. Ginzburg C. Sinais: raízes de um paradigma indiciário. In Ginzburg C. Mitos, emblemas e sinais. São Paulo: Editora Schwarcz; 1989. p. 143-180.

12. Williams R. Palavras-chave: um vocabulário de cultura e sociedade. Vasconcelos SG, tradutor. São Paulo: Boitempo; 2007.

13. Vigarello G. Treinar. In Corbin A, Courtine JJ, Vigarello G. História do corpo: da Revolução à Grande Guerra. Petrópolis, RJ: Vozes, 2012. p. 197-250.

14. Petroski E. Antropometria: técnicas e padronizações. 3. Ed. Blumenau, SC: Nova Letra; 2007.

15. Geertz C. Nova luz sobre a antropologia. Rio de Janeiro: Zahar; 2001.

16. Hessen J. Teoria do conhecimento. Correia A, tradutor. 1. ed. Coimbra: Arménio Amado; Brasil: Martins Fontes; 2000.

17. Twietmeyer G. What is Kinesiology? Historical and Philosophical Insights. Quest 2012;64(1):4-23.

18. George HS. Resurrecting Thirty Years of Historical Insight About Kinesiology: A Supplement to "What is Kinesiology? Historical and Philosophical Insights". Quest 2013;65(2):133-138.

19. Quelhas AA, Nozaki HT. A formação de professores de educação física e as novas diretrizes curriculares frente aos avanços do capital. Rev Motriviv 2006; 26: 69-87.

20. Rocha M, Araújo C; Gomes P, Fleugner A. Fisiologia do Exercício. Lamartine D, organizador. Atlas do Esporte no Brasil. Rio de Janeiro: CONFEF; 2006.

21. Matsudo V. Entrevista. Rev Adm Saúde 2010; 12(46): 3-6.

22. Artigo de jornal que traz a notícia do apoio governamental nas universidades em relação a disciplinas como biometria e biomecânica. Jornal dos Sports. Rio de Janeiro. 21 out 1977; Hemeroteca Digital Brasileira: 4.

23. Hunger DACF, Souza Neto S, Pereira JM, Franco FC, Rossi F. Formação acadêmica em Educação Física: "Corpos" (Docente e Discente) de conhecimentos fragmentados. Motriz: J Phys Ed 2009; 15(1): 79-91. 
24. Mazo J. Os laboratórios de pesquisa do exercício: algumas considerações. Mov 2000;(VI): 8-10.

25. Mazo J. A criação do Laboratório de Pesquisa do Exercício da Escola de Educação Física da UFRGS. Mov 2000;(VI): 11-22.

26. Oliveira MAT. Esporte e Política na ditadura militar brasileira: a criação de um pertencimento nacional esportivo. Mov 2012; 18(4): 155-174.

27. Daolio J. Educação Física Brasileira: Autores e Atores da Década de 80. [Tese de Doutorado]. Campina, SP: Universidade Estadual de Campinas; 1997.

28. Calciolari Júnior A. As políticas públicas de ensino superior, ciência e tecnologia e educação no Brasil como determinantes da significação da educação física brasileira como campo científico. [Tese de Doutorado - Pós-Graduação Stricto Sensu em Educação Física Associado UEM/UEL]. Londrina, PR: Universidade Estadual de Londrina; 2017.

29. Caram EM. Considerações sobre o desenvolvimento da educação física no ensino superior. Rev Bras Ciênc Esporte 1983; 4(2): 59- 65.

30. De Rose EH. Técnicas de avaliação da composição corporal. Rev Med Esporte 1973; 1(1):45-8.

31. Araújo C. O Colégio Brasileiro de Ciências do Esporte: um comentário sobre suas etapas iniciais. Rev Bras Ciênc Esporte 1998: 50-53.

32. Silva DAS, Petroski E. Revista Brasileira de Cineantropometria e Desempenho Humano: trajetória e perspectivas. Rev Bras Cineantropom Desempenho Hum 2014; 16(1): v-vi.

33. The International Society for the Advancement of Kinanthropometry - ISAK. 2018. Disponível em: <https://www.isak.global/WhatIsIsak/\#GoToKina > [2019 jul 15]

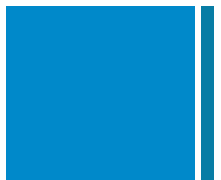

Corresponding author

Carolina Fernandes da Silva

Campus Universitário, Trindade 88040-900,

Florianópolis, SC, Brasil.

Email: carolina.f.s@ufsc.br 